증 례

\author{
염증성 가성폐종양 2 예 \\ 연세대학교 의과대학 내과학교실 \\ 이 훈·손희영・안철민·김성규・김기호
}

$=$ Abstract $=$

\title{
Two Cases of Inflammatory Pseudotumors of the Lung
}

\author{
Hoon Lee, M.D., Hee Young Sohn, M.D., Chul Min Ahn, M.D. \\ Sung Kyu Kim, M.D. and Kiho Kim, M.D. \\ Department of Imternal Medicine, Yonsei University College of Medicine
}

\begin{abstract}
The inflammatory pseudotumor is non nepolastic pulmonary mass lesion of unknown etiology composed of a variety of inflammatory and mesenchymal cells, including plasma cells, histiocytes, mast cells, lymphocytes and spindle shaped mesenchymal cells.

These different types of cells occur in varing unmbers in different areas of the same lesion, and this variability of appearence has given rise to the large numbers, such as plasma cell granuloma, pseudotumor, histiocytoma, xanthoma, fibroxanthoma, solitary mast cell granuloma etc. The author report two cases of inflammatory pseudotumor with the brief review of references.
\end{abstract}

\section{서 론}

염증성 가성폐종양은 원인이 확실치 않으나, 조직학적 으로 염증세포와 섬유조직이 많이 나타나는 것이 특징으 로 임상적, 병리소견상 또는 X-선상 결핵성 육아종이나 악성종양, 그중에서도 특히 전이성 악성종양과 혼동되기 쉅기 때문에 진단시 문제가 야기되곤 한다.

이 질환은 약 반수에서 증세없이 우연히 발견되며 수 술로 완전히 치유되는 것으로 알려져 있다. 국내에서는 유드이이 주기관지에 발생한 염증성 가종양을 보고 했으 나, 비교적 드물게 보는 질환으로, 저자들은 최근에 수 술로 완치된 1 예와 4 년의 간격을 두고 각기 다른 부위에 병변이 생겨 또 수술로 치료헌 1 예를 경험하였기에 보고 하고자 한다.

\section{증 례}

\section{증례 1}

환 자:여자, 24 세

병 력 : 평소 건강하였으며, 약 1개월전 기침과 발열 이 있어 개인병원을 방문, 단순 홍부 X-선촬영상 우폐
하야에 종괴가 발견되어, 확진 및 치료를 위해 전원되었 다.

이학적 소견 : 외견상 건강하게 보였고, 입 원당시의 혈 압, 체온, 호흡수는 정상이었다. 청색증이나 곤봉상수지 는 없었고 흥부진찰상 나음은 들리지 않았으며, 호흡음 도 감소되어 있지 않았다.

검사 소견 : 혈색소치 및 hematocrit치는 정상이었고, 백혈구수는 $10,300 / \mathrm{mm}^{3}$ 이었으며, 그중 분절중성구가 $78 \%$, 임파구 $20 \%$, 단핵구 $2 \%$ 였다. 객담은 3 회의 결 핵균 도말검사에 음성을 보였고, Gram 염색 및 배양검 사에서 특기할 만한 소견이 없었다. 뇨검사, 간기능검사 등도 정상범위내였으며, 기관지경을 통한 우하엽 기관지 세척액의 세포진검사에서 암세포는 보이지 않았고, 결핵 균도말검사 및 $\mathrm{Gram}$ 염색에서도 모두 음성이었다. 경 기관지폐생검에서도 비특이성 염증세포의 증식 이외에는 특이한 소견이 없었다.

흉부 X-선 소견 : 우폐하야에 주위와 경계가 분명하고 석회화나 공동이 없는 원형의 종괴가 보였다(Fig. 1, 2).

병리조직 소견

1) 육안적 소견 : 우폐하엽의 상, 후분절 부위에 황 색을 띠는 $4 \times 4 \times 4 \mathrm{~cm}$ 크기의 종괴가 있었다.

2) 현미경 소견 : 방추형의 섬유아세포가 많이 나타 
나고, 심한 초자질변성이 있었으며, 성숙한 염증세포가 그 사이에 분포되어 있는 것을 볼 수 있었다(Fig. 3,4 ).

\section{증례 2}

환 자 : 여자, 46 세

병 력 : 4년전 객혈이 있어 본원에 내원, 좌페상엽에

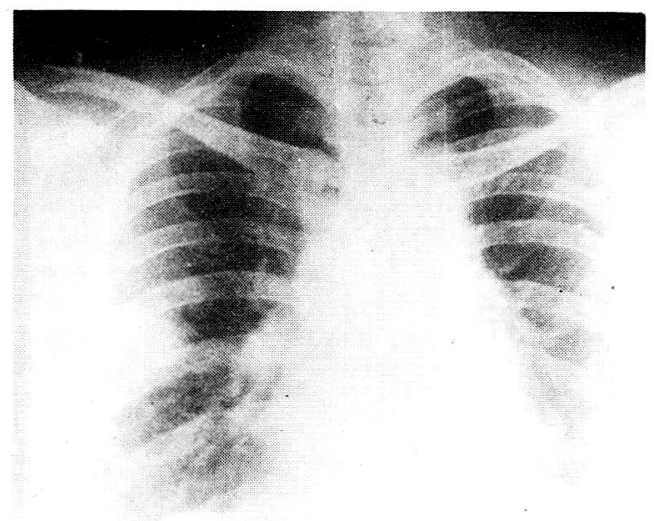

Fig. 1. Chest X-ray on admission, showing well demarcated round mass in the right lower lung field (Case 1).
종괴가 발견되어 염증성 가성폐종양 진단하에 좌폐상엽 절제술을 받고 별 문제없이 지내다가 3 개월전부터 객혈 이 재발되어 단순 홍부 $\mathrm{X}$-선을 재촬영하였는데, 우폐중 엽에 종괴가 있는 것을 발견하였다.

이학적 소견 : 결막색조는 창백하지 않았고 청색증이나 곤봉상수지도 없었다. 흥부 청진상 나음이나 호흡음의 감

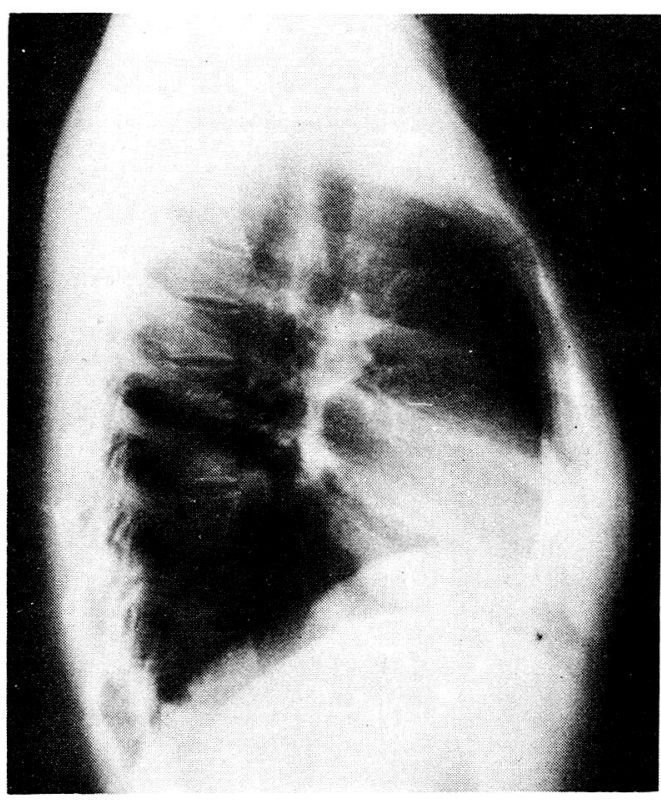

Fig. 2. Right lateral view : homogeneous well defined round mass in the lower lobe (Case 1).

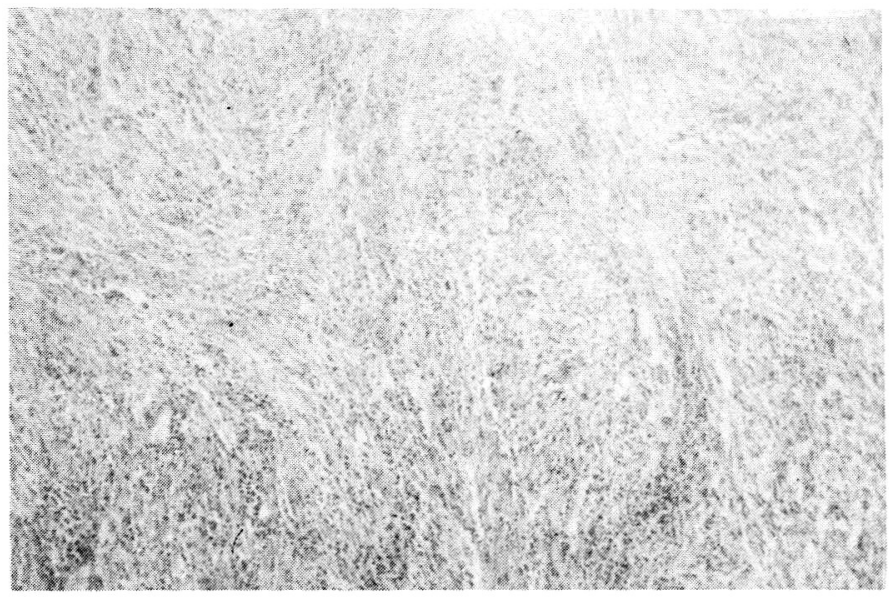

Fig. 3. The spindle-shaped mesenchymal cells occasionally forming fascicles simulating connective tissue tumor admixed with numerous inflammatory cells (H\&E, 100X) (Case 1). 
소는 없었다.

검사 소견 : 혈샐소치 $12.2 \mathrm{gr} / \mathrm{dl}$, hematocrit치 $35 \%$, 백혈구 $5,900 / \mathrm{mm}^{3}$ 였으며 Albmin $4.0 \mathrm{gr} / \mathrm{dl}$, Alkaline phosphatace 41 IU/L, SGOT 13 IU/L, SGPT 26 IU/ L, TG $76 \mathrm{mg} / \mathrm{dl}$, HDL-Cholesterol $44 \mathrm{mg} / \mathrm{dl}$ 로 모두 정상소견을 보였다. 객담은 3 회의 결핵군도말 및 $\mathrm{gram}$ 염색검사에서 특기할 만한 소견이 없었고, 세포진검사에
서도 암세포는 보이지 않았다.

흥부X-선 소견 : 우폐상엽에 동질성의 종괴가 보였다 (Fig. 5, 6).

단층촬영에서 석회화나 공동은 보이지 않았다.

병리조직학적 소견 : 재수술에서의 조직학적 소견은 첫 번째 수술소견과 비슷하였다. 즉, 돌출된 폐모층이 있고 그 사이에 세포성분들이 꽉 차 있는 것을 볼 수 있었고,

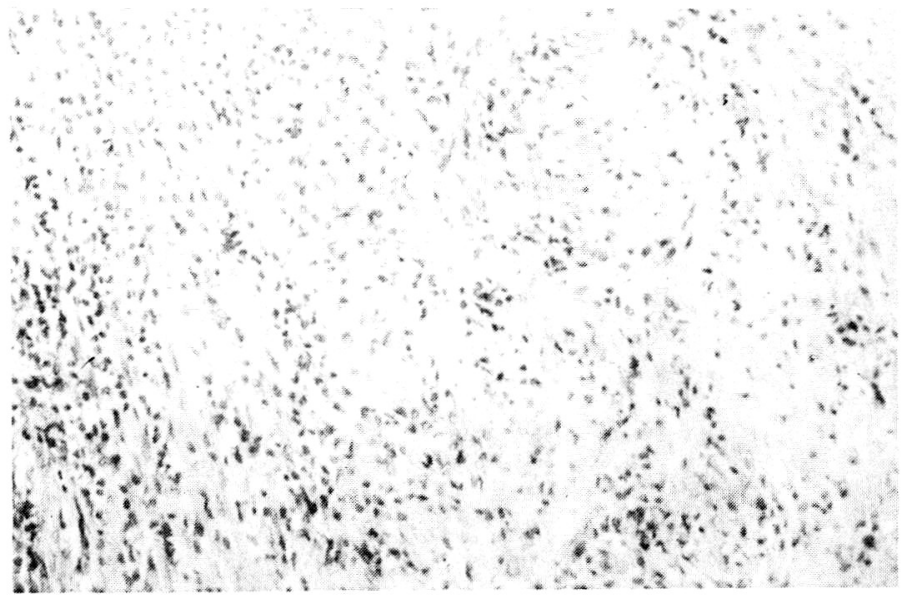

Fig. 4. The fibroblast-like spindle cells accompanying hyalinization and numerous plasma cells and lymphocytes infiltrated (H\&E, 400X) (Case 1).

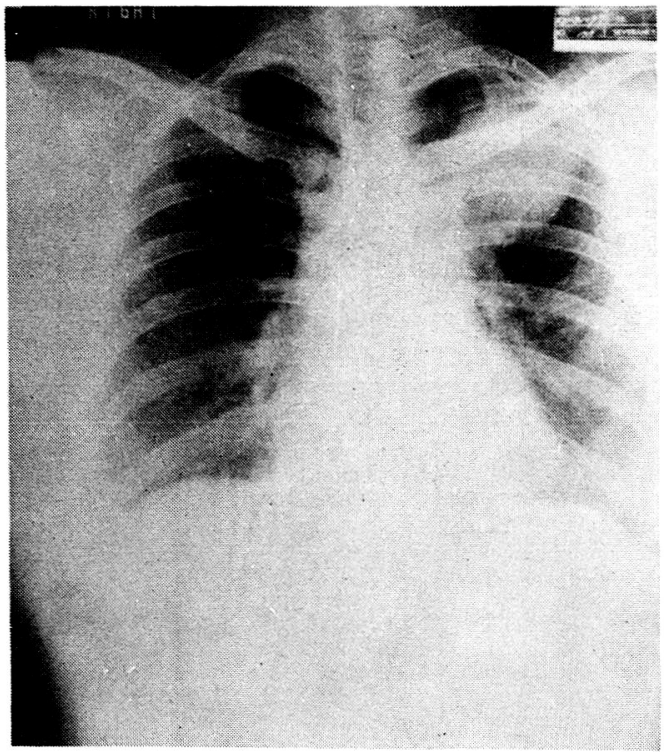

Fig. 5. Chest X-ray on admission, showing homogeneous round mass in the left upper lung field (Case 2).

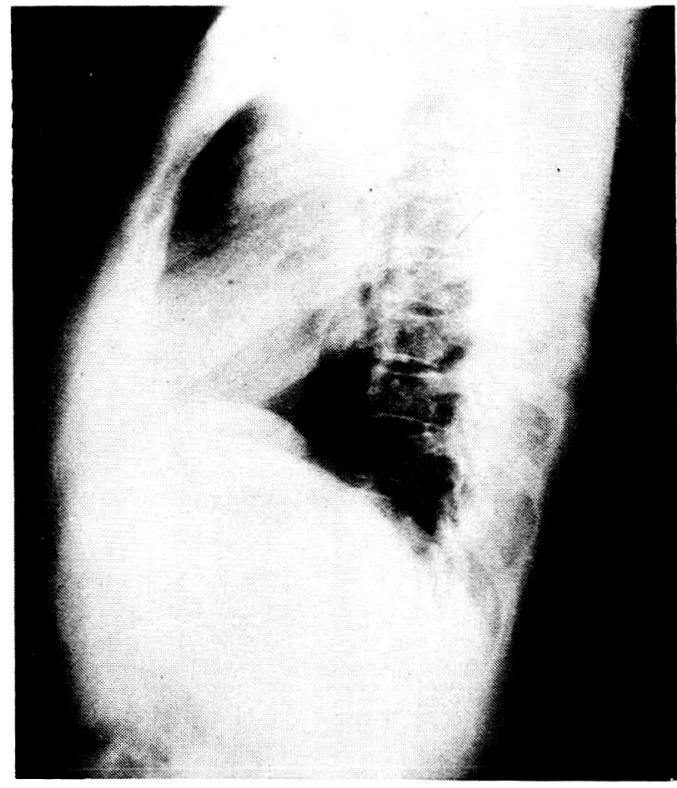

Fig. 6. Left lateral view: homogeneous well defined large mass in the upper lobe (Case 2). 


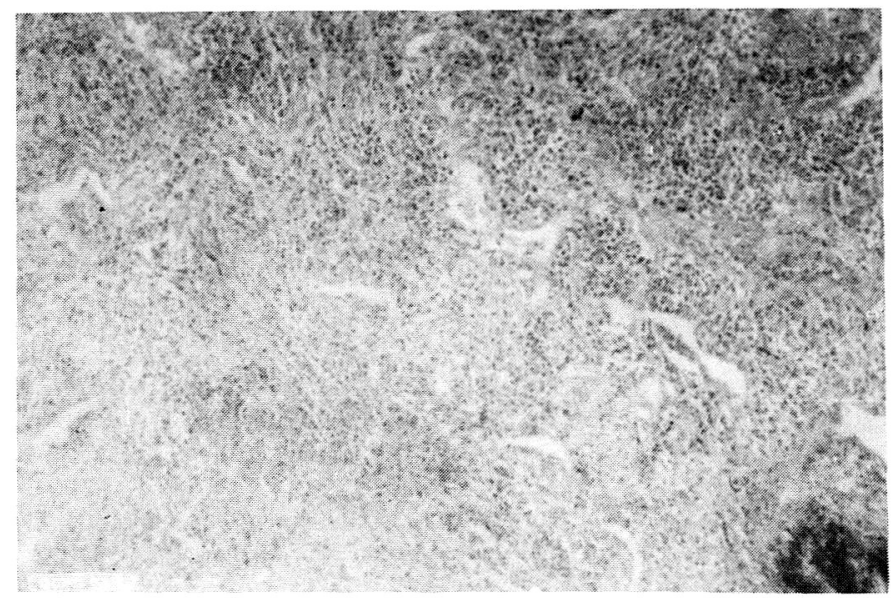

Fig. 7. Admixture of large amounts of inflammatory cells and spindle cells with entrapped many air-spaces (H\&E, 100X) (Case 2).

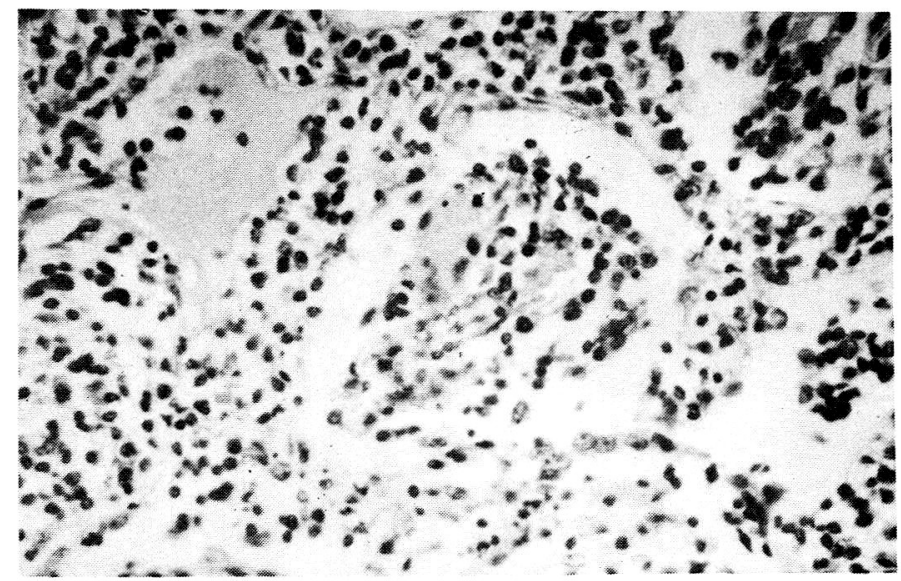

Fig. 8. Characteristic many plasma cells and lymphocytic infiltration within bronchiole in center and surrounding interstitial tissue ( $\mathrm{H} \& \mathrm{E}, 400 \mathrm{X}$ ) (Case 2).

혈 관분포도 풍부했으며, 광학대상 세포들은 대부분 성숙 한 염증세포임을 알 수 있었다(Fig. 7,8 ).

\section{고 안}

염증성 가성폐종양에 대해서는 1939년 'Brunn'에 의 해 기침과 발열을 주된 증세로 내원하여 결핵성 육아종 이나 악성종양을 의심하였으나 수술결과 밝혀진 환자가 처음으로 보고되었고 ${ }^{2)}, 1948$ 년 Scott등에 의해 조직구 내에 지방질이 많이 함유되어 있다고 하여 'Xanthoma of the lung'이라고 명명되어 보고 되었으며 ${ }^{3)}$, 1954년 Umiker와 Iverson에 의해 'Inflammatory Pseudotu- mor of the lung' 이라고 명명되면서,

1) 형태학적으로 종양과 유사해야 하며,

2) 임상적으로는 호흡기 감염의 과거력이 있고, X-선 상 결핵종이나 악성종양의 의심을 품게 하고,

3) 조직학적으로 종괴내에 많은 양의 염증세포와, 성 숙한 섬유세포조직, 종괴 절반에 걸쳐 폐실질의 잔재인 탄성섬유와 혈관이 있어야 하며, 유사분열이 없어야 한 다는 진단적 기준이 정해졌다4). 그후 여러 사람에 의해, 주종을 이루고 있는 구성성분에 따라, 황색육아종 $3,5,6)$, 형질세포종), 결합조직세포 육아종 ${ }^{8)}$, 조직구종9), 형질 세포 육아종 ${ }^{10 ~ 12)}$, 경화성혈 관종등 ${ }^{13 ~ 16)}$ 으로 불리워지면 서, 같은 일단의 병변으로 보는 사람들도 있었으나, 경 
화성 혈 관종이나, 형질세포종, 결합조직세포 육아종 등 과는 별개의 질환으로 분류하는 경향이 있다.

1956년 Liebow와 Hubbell에 의해서 광학현미경으로 7예의 경화성, 혈관종에 대한 묘사가 있었는데, 출혈을 동반한 혈관의 증식과 출혈에 대한 세포반응으로 조직세 포가 증가하는 것이라고 하였고, 염증성 가성 폐종양과 경 화성 혈관종의 근본적인 차이점은 명백한 혈관종증의 요 소가 존재하느냐, 존재하지 않느냐 하는데 있다고 하였 다 ${ }^{13)}$.

1972년 Joel등도 같은 결과를 발표하여 이 이론을 뒷 받침하여 주었다 ${ }^{16)}$. 또 Mori는 '황색종은 경화성 혈관 종의 노화과정중 말기에 생기는 상태'라는 가설을 내세 웠다 ${ }^{14)}$. Gray는 상피세포의 증식과 현저한 혈관의 분포 가 있고, 방추세포나 염증세포가 많이 않은 것이 혈 관종 의 특징이라 하여 앞서 말한 유사한 폐 종괴와의 감별을 분명히 하였다 ${ }^{15)}$. 형질세포 육아종과 형질세포종은 뚜렷 한 차이가 있는데, 육아종성의 병변은 형질세포와 다형 핵백혈구, 임파구, 섬유아세포, 대식세포 그리고 증식하 는 혈관들로 이루어져 있고, 주종을 이루는 세포가 형질 세포인 경우이고, 형질세포종은 결합조직이 드물게 보이 고, 형질세포가 집락을 이루거나 엽을 이루고 있는 것이 달. Robson과 Knudson등에 의해 조직학적으로 형질 세포 육아종으로 진단된 환자중 5 개월 뒤 단백질 이상을 보였고, 25 개월 뒤에는 파종성질환으로 사망한 예를 보 고 하였는데 ${ }^{7)}$, 형질세포 육아종과 결합조직세포 육아종 은 matachromatic 염색을 하기전에는 조직학적으로 구 별이 매우 힘들며, 이 염색법은 혼히 시행하지 않기 때 문에 이런 예에서는 결합조직세포 육아종으로 오진할 가 능성이 높다고 하였다.

이런 결합조직세포 육아종은 대개 전신적으로 어디나 발생할 수는 있으나, 폐를 침범하는 경우는 드물고, 형 질세포육아종으로 보고된 예중 실제로는 결합조직세포 육아종일 경우가 적지 않을 것이라고 하였달. 결국 이 런 질환들을 제외한 순수한 가성폐종양의 병인에 대한 명 확한 결론은 내려지지 않고 있으나, 약 반수 이상에서 호 흡기 감염후에 오는 것으로 미루어, 비특이성 염증반응 의 일종이 아닌가 하는 가정을 할 수 있다 ${ }^{4,6,17,18)}$. 염증 성 가성폐종양은 약 $1 / 3$ 정도가 20 세미만에서 발생하는 것으로 되어 있고 ${ }^{12,17)}$, 그 외의 연령층에서는 비슷하게 발생하며, 남녀비도 같은 정도로 나타난다고 하였다.

증상으로는 약 반수에서 마른기침, 객혈, 훙통등이 있
을 수 있으나, 나머지반에서는 아무 증세없이 우연히 발 견된다 ${ }^{6,17,18)}$. 크기는 $1 \sim 8 \mathrm{~cm}$ 으로 다양하며, $\mathrm{X}$-선상엔 주위와 경계가 분명한 동질성의 종괴가 단독 혹은 다발 로 올 수 있다 ${ }^{6,12,17)}$.

우측폐가 좌측폐보다 2 배정도 호발하며 육안적으로는 황색을 띠는 경우가 많고 부드럽게 만져진다고 한닿. 예후는 극히 좋아서 수술로 완전한 치유를 기대할 수 있 으나 ${ }^{6,12,17)}$ 불충분하게 제거되면 재발할 수 있다고 한다 ${ }^{1)}$. 본원에서 경험한 예는 모두 여성에서 발생하였으며, 종 괴가 단독으로 왔고, 내원전에 경미한 기관지염의 증세 가 있었다. 증례 1 은 입원 7 일째 우폐하엽 절제술을 시 행하였고, 그후 외래 내원중 훙부 X-선 추적검사상 병 변이 완전히 치유되었음을 보여주고 있다.

증례 2 는 수술을 했음에도 불구하고 종괴가 대측폐에 다시 발생하여 재수술하였던 환자로서 병리소견상 최초 수술시의 병리소견과 동일한 소견을 보였으며 현재 외래 에서 추후관찰중에 있다.

\section{결 론}

저자는 연 세 대학교 의 과대학부속 세브란스병 원 내과에 서 경험하였던 염증성 가성폐종양 2예를 보고하였다.

\section{REFERENCES}

1) 유세화, 국상표, 서순규, 김형묵, 최종상 : 좌측 주기 관지에 발생한 염증성 가종양. 대한내과학회잡지 27 : 1520. 1984

2) Brunn $\mathrm{H}$ : Two interesting benign lung tumors. J Thoracic Surg 9:119, 1939

3) Scott H, et al: Solitary Xanthoma of lung. J Thoracic Surg 17:821, 1948

4) Umiker WO, et al: Post inflammatory "Tumor" of the lung. J Thoracic Surg 28:55, 1954

5) Jack L, et al: Xanthomatous and inflammatory pseudotumor of the lung. Cancer 15:522, 1982

6) Wentworth $P$, et al: Xanthomatous pseudotumor of lung. Cancer 22:345, 1968

7) Robson AO, Knudsen A: Plasmacytoma of lung and stomach. Brit J Dis Chest 53:62, 1959

8) Edmond E, et al: Solitary mast cell tumor of lung. Arch Inter Med 9:118, 1966

9) Spencer H: Pathology of the lung. 2nd Oxford pergamon press 1968 
10) Spyker MA, et al: Plasma cell granuloma of mediastinal Lymph node with extension to right lung. J Thoracic Surg 31:211, 1956

11) Babador M, Liebow AA: Plasma cell granulomas of the lung. Cancer 31:191, 1973

12) Grover $\mathrm{E}$, et al: Unusual presentation of pulmonary inflammatory pseudotumor as esophageal obstruction. Am J Gastroenterology 71:501, 1979

13) Liebow AA, Hubbell DS: Sclerosing hemangioma of the lung. Cancer 9:53, 1956

14) Mori S: Sclerosing hemangioma of the lung. Chest
54:381, 1968

15) Gary S, et al: Electron microscopic study of so-called "pulmonary sclerosing hemangiomas". Cancer 30:1092, 1972

16) Joel E, et al: Ultrastructure of a sclerosing hemangioma of the lung. Cancer 30:512:1972

17) Donald Ck: Ultrastructual study of a postinflammatory "Tumor" of lung. Cancer 36:149, 1975

18) Natalie $S$, et al: Inflammatory pseudotumors of the lung. Br J Rad 47:94, 1974 